\title{
Communication
}

\section{Evaluating the Pollution Risk of Soil Due to Natural Drainage of Orange Peel: First Results}

\author{
Serafina Andiloro ${ }^{1}$, Paolo Salvatore Calabrò ${ }^{2, *}\left(\mathbb{C}\right.$, Adele Folino ${ }^{2}(0)$, Demetrio Antonio Zema ${ }^{1}(\mathbb{D}$ \\ and Santo Marcello Zimbone ${ }^{1}$ \\ 1 Department of Agriculture, Mediterranean University of Reggio Calabria, Località Feo di Vito, \\ I-89060 Reggio Calabria, Italy; serafina.andiloro@unirc.it (S.A.); dzema@unirc.it (D.A.Z.); \\ smzimbone@unirc.it (S.M.Z.) \\ 2 Department of Civil, Energy, Environmental and Material Engineering, Mediterranean University of Reggio \\ Calabria, Località Feo di Vito, I-89022 Reggio Calabria, Italy; adelefolino@alice.it \\ * Correspondence: paolo.calabro@unirc.it; Tel./Fax: +39-0965-312681
}

check for updates

Citation: Andiloro, S.; Calabrò, P.S.; Folino, A.; Zema, D.A.; Zimbone, S.M. Evaluating the Pollution Risk of Soil Due to Natural Drainage of Orange Peel: First Results. Environments 2021, 8, 43. https://doi.org/10.3390/ environments 8050043

Academic Editor: Paula Alvarenga

Received: 20 April 2021

Accepted: 10 May 2021

Published: 12 May 2021

Publisher's Note: MDPI stays neutral with regard to jurisdictional claims in published maps and institutional affiliations.

Copyright: (c) 2021 by the authors. Licensee MDPI, Basel, Switzerland. This article is an open access article distributed under the terms and conditions of the Creative Commons Attribution (CC BY) license (https:// creativecommons.org/licenses/by/ $4.0 /)$.

\begin{abstract}
Orange peel (OP), the main residue of the citrus industry, is usually used for animal feeding and soil fertilisation if more advanced options are lacking. In areas with warm and dry climatic conditions, OP is land-spread for solar-drying on the fields, the leachate produced is a potential pollution factor for soil especially due to the release of organic matter; heavy rainfalls could even aggravate the hazard. Since literature does not report any quantitative evaluation of this risk, this study presents three OP drainage tests in lysimeters, where OP was left releasing leachate on a soil layer. A first test was carried out on raw OP naturally draining, while, in a second and a third test, a rainfall of $100 \mathrm{~mm}$ was applied on already drained and solar-dried OP, respectively. After drainage, raw OP reduced its initial volume by about $90 \%$ and the leachate production accounted only for about $20 \%$ of the initial volume. The simulated rainfall produced even lower volumes of leachate (2-3\% of the initial biomass volume), in spite of the high rainfall volume and long drainage time after its application. The COD concentration in the leachate from the raw OP was significantly higher than those produced after simulated rainfall. However, the COD amount released to the soil was negligible. The lysimetric tests showed that the release of leachate occurs mainly during the first phase of drainage and that rainfall is absorbed and does not produce significant leaching. Overall, the risk of soil pollution due to the natural drainage of OP is negligible, due to both limited amounts of leachate and organic loading.
\end{abstract}

Keywords: orange peel; rainfall simulation; lysimeter; leachate; natural drainage; solar drying

\section{Introduction}

The orange, which is the most widely-cultivated fruit worldwide, is about $50-60 \%$ of total citrus species production (specifically orange, tangerines, lemons, limes and grapefruits) [1,2]. In Italy, orange production accounted for $64 \%$ of the citrus fruits in 2018 [2]. Part of the produced oranges are addressed to processing industry mainly for juice production, and for preparing other food products (such as jam, paste, marmalade) [2]. Other marketable by-products obtained from processing oranges consist of: essential oils (utilised as food and beverage flavours and preservation, in the perfume industry and for other applications) [3-5], which mainly contain $d$-limonene (used as feedstock for adhesives, degreasers, flavours, cleaners and solvents) [6-9], flavonoids and limonoids (required for pharmaceutical and medical applications) [1,10-12].

As a consequence, solid ("orange peel", hereinafter OP, which accounts for 55 to $65 \%$ of the total weight of the processed fruits, according to the processing method) and liquid ("citrus wastewater") residues of orange processing are produced in large amounts and their management is expensive. Moreover, their physico-chemical properties may induce 
heavy environmental damage to soil and water bodies, if these residues are not properly managed [13,14].

Innovative valorisation patterns for OP are mainly addressed to the recovery of energy in the forms of biomethane (by anaerobic digestion process) and bioethanol (by alcoholic fermentation of sugars [15]) as well as the production of added-value compounds (e.g., pectins, dietary fibres, flavonoids, flavouring agents, citric acid, etc.) under a biorefinery perspective. Although being promising, some economical and technical constraints still limit these uses [1,9]. In particular, the sensitivity of the microorganisms to the presence of essential oils limits the methane yields in biochemical processes of the full-scale anaerobic digesters. Similarly, the high concentrations of the essential oils in citrus residues limits the energy yields of alcoholic fermentation, which requires expensive pre-treatments to make fermentable sugars from pectin, cellulose and hemi-cellulosic polysaccharides fermentable $[1,16]$. Therefore, the use of $O P$ as animal food or organic soil conditioner (directly or after composting) are traditional and common methods for its management.

Composting allows the complete bioconversion of the OP in a useful soil conditioner, but this process requires long time (many weeks or some months) and energy supply to keep an adequate level of oxygen. OP compost was found to be beneficial for plant growth in field crops, nursery [17] and potting at proper dosages, inducing larger increases in root length, surface area, root dry weight, fineness and tissue density of the tested plants $[18,19]$. When more advanced options lack, the traditional use of OP as food for animals (wet or ensiled [20,21] or dried [22,23]), thanks to its nutritional and beneficial properties, is advisable in areas with high livestock density, since the costs of its transportation to the farm may be too high [24].

Some studies have also shown the improvement in the organic matter and nutrient contents of soil after the direct use of OP as organic conditioner; for this use, also the maximum benefit is obtained with the spreading on agricultural land in proximity to citrus processing industries. Moreover, the use of $\mathrm{OP}$ as soil conditioner was found to improve the resistance to raindrop impacts and erosion $[1,9,25]$. The impacts of erosion are increasing in several countries, due to society socio-economic transformation, which has mostly focused on improving living conditions, while not considering the inevitable negative effects of spatial changes in rural areas [26,27]. This form of land degradation, although being diffused worldwide, constitutes a major issue in Mediterranean countries [28]. On the other hand, the utilisation of OP as soil conditioner is strongly limited by the high water content of the fresh by-product (about $86 \%$ in weight), which increases the costs of biomass management, conservation and transport [29] from the production to the land-spreading sites. For the same reason, the OP is not suitable for the energy conversion by thermal treatments (such as pyrolysis) or for uses as fuel for heat and power plants $[1,30,31]$.

Some investigations have shown the opportunity to dry OP in open air in those environments with hot and dry climate. This makes the OP use in agriculture and animal breeding easier and cheaper [32,33]. After land spreading, the external layers of OP naturally dry-up due to solar energy with a crust slowly developing in depth. The crust can be removed by agricultural machines, in order to make the drying process faster and then the removed material can be used as animal feed [20,23]. The biomass underlying the crust is subject to physical and biochemical processes (pectin degradation, acid lactic fermentation) as for ensiled OP [34,35]. However, the natural drying of OP in open air releases leachate with a high content of organic matter. This leachate is thought to be a potential cause of pollution for soil, water bodies and groundwater $[9,36]$. Leachate produced from citrus fruit has, indeed, an acidic $\mathrm{pH}$, high turbidity and high contents of chemical oxygen demand (COD) and total suspended solids [37]. The occurrence of heavy rainfalls in the Mediterranean environments may aggravate (by increasing the leachate volume) or reduce (by diluting the concentration of polluting compounds released by the $\mathrm{OP})$ the pollution potential of naturally drying OP. To the best of the authors' knowledge, although the process is common in farming in the Mediterranean area, no experiences evaluating this risk due to OP drainage in open air are available in literature. 
To fill this gap, this paper proposes a first series of tests evaluating the natural drainage of land-disposed OP in lysimeters, where the drying biomass was left releasing leachate on a soil layer. Heavy rainfall simulations have been carried out to evaluate the concentration or dilution effects due to precipitation. This study proposes first indications about the possible pollution risks due to the leachate release of drying-up biomass exposed or not to rainfalls.

\section{Materials and Methods}

\subsection{Description of the Experimental Tests}

The OP tested in this study was obtained in a large citrus industry of Sicily (Southern Italy) by mechanical pressing.

The OP drainage tests were carried out using home-made cylinder-shaped lysimeters ( $0.7 \mathrm{~m}$ in diameter and $1.15 \mathrm{~m}$ in height), each one with a volume of $442 \mathrm{~L}$ (Figure 1).

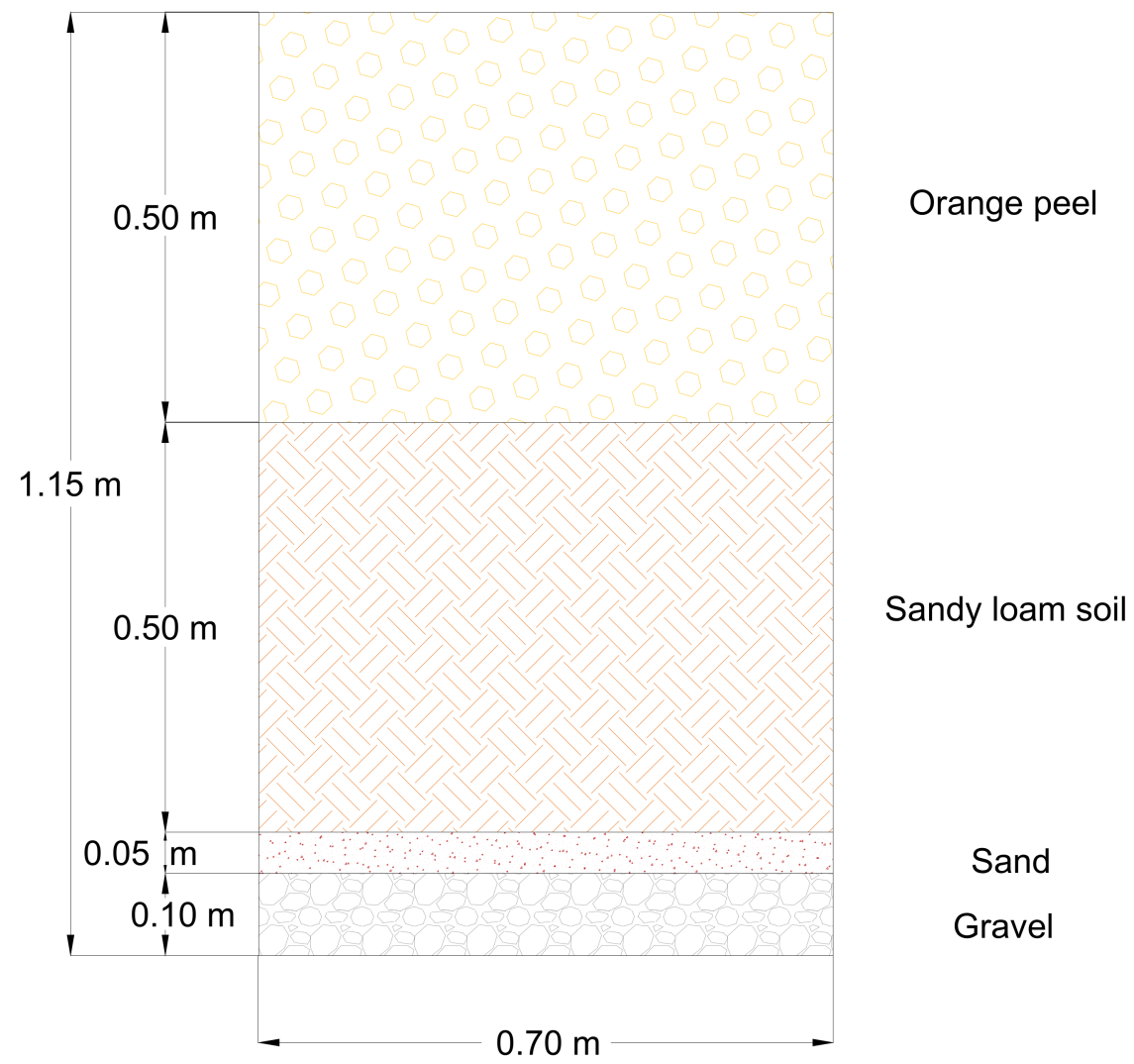

Figure 1. Layout of the orange peel/soil column at the start-up of each lysimetric test.

Three drainage tests were carried out:

- $\quad$ Raw OP (“R" test);

- Already naturally-drained OP ("ND" test), then exposed on day 39 to a simulated rainfall of $100 \mathrm{~mm}$ (equivalent to about $38.5 \mathrm{~L}$ and to $20 \% v / v$ of the OP volume);

- Already solar-dried OP ("SD" test), then exposed to the same simulated rainfall.

More specifically, " $\mathrm{R}$ " test simulates OP natural drainage due to land-spreading immediately after the OP production, while "ND" and "SD" tests explore the effect of rainfall on previously drained or solar-dried OP in terms of quantity and quality of leachate produced.

Before the test, fresh OP was treated with $0.5 \% w / w$ of calcium oxide (Merck, Darmstadt, Germany), which is the commonly used dose [1], to reduce the water content of OP. $\mathrm{CaO}$ reacts with pectin and limits their hygroscopicity, thus increasing water loss [1,12].

The lysimeter was first filled with two layers of gravel $\left(0.1 \mathrm{~m}, \mathrm{D}_{50}=2 \mathrm{~mm}\right)$ and sand $\left(0.5 \mathrm{~m}, \mathrm{D}_{50}=0.5 \mathrm{~mm}\right)$, to easily collect the leachate. Sandy loam soil $(0.5 \mathrm{~m})$ was then put on 
these layers, and finally the remaining volume $(0.5 \mathrm{~m})$ of the lysimeter was filled with OP as described above. Due to the relatively high hydraulic conductivity of this soil, almost all the leachate produced by the overlaying OP drained without being retained.

During the OP drainage, the biomass depth and the leachate volume (collected in a tank below the lysimeter) were monitored twice a week.

\subsection{Soil, $O P$ and Leachate Characterisation}

A sandy loam soil was used, since this texture is very common in agricultural lands of Southern Italy [38,39]. Table 1 reports the main properties of this soil (USDA soil classification), determined over the air-dried fraction finer than $2 \mathrm{~mm}$. In samples of this soil, $\mathrm{pH}$, organic matter, total nitrogen, available phosphorous, exchangeable potassium, calcium, sodium and magnesium, were measured before the tests.

Table 1. Main physico-chemical properties of the sandy loam soil used in the lysimetric tests.

\begin{tabular}{cccc}
\hline Parameter & Method & $\begin{array}{c}\text { Measuring } \\
\text { Unit }\end{array}$ & Value \\
\cline { 1 - 2 } $\mathrm{pH}$ & - & - & 9.0 \\
\cline { 1 - 2 } Organic matter & Walkey and Black method, 1934 [40] & \% weight & 1.5 \\
\cline { 1 - 2 } Total nitrogen & Bremmer and Mulvaney method, 1982 [41] & & 1.4 \\
\hline
\end{tabular}

The following parameters were evaluated on OP samples: $\mathrm{pH}$, electrical conductivity and dry matter. The results of physico-chemical characterisation of the OP are reported in Table 2. At the end of the test on the leachate released by OP, COD [42], $\mathrm{pH}$ and electrical conductivity were determined.

Table 2. Main physico-chemical properties of the raw OP used in the lysimetric tests.

\begin{tabular}{cccc}
\hline Parameter & Instrument or Method & $\begin{array}{c}\text { Measuring } \\
\text { Unit }\end{array}$ & Value \\
\hline $\mathrm{pH}$ & $\mathrm{pH}$-meter, Hanna Instruments HI98230 & - & 7.3 \\
\hline Dry matter * & $\begin{array}{c}\text { Oven drying at } 105^{\circ} \mathrm{C} \text { until weight } \\
\text { stabilisation }\end{array}$ & $\%$ & 15.6 \\
\hline $\begin{array}{c}\text { Electrical } \\
\text { conductivity }\end{array}$ & $\begin{array}{c}\text { Portable conductivimeter, Hanna } \\
\text { Instruments HI933000 }\end{array}$ & $\mathrm{mS} \mathrm{cm}^{-1}$ & 1.7 \\
\hline${ }^{*}$ weight percentage on fresh orange peel.
\end{tabular}

\section{Results and Discussion}

In about 14 weeks, the volume of the OP in lysimeters decreased by about $90 \%$ of the initial value in all tests with extremely similar trends (Figure 2). The high reduction in OP volume is mainly due to the evaporation of a high volume of water [34] accompanied by the compaction of the biomass. In contrast, the leachate amounts noticeably varied between the raw OP and the other two biomasses subjected to rainfall (Figure 3). In more detail, in the " $R$ " test, the OP naturally draining released a leachate volume of 37.7 L (Figure 3), which is $21 \%$ of the total volume reduction and $19 \%$ of the initial volume of OP. 


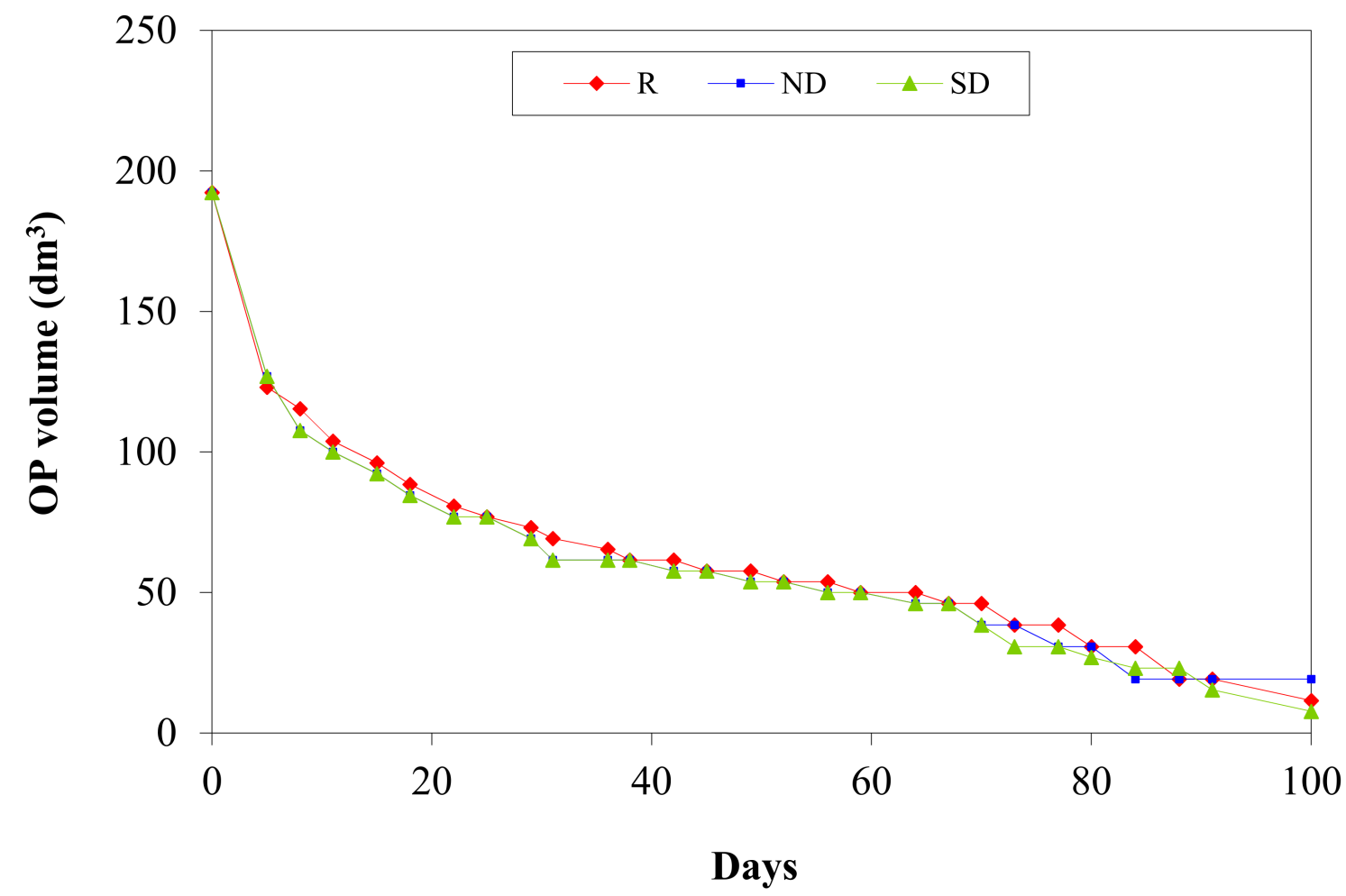

Figure 2. Temporal variation of OP volumes in the lysimetric tests (R, raw OP; ND, naturally drained OP + rainfall; SD, solar-dried OP + rainfall).

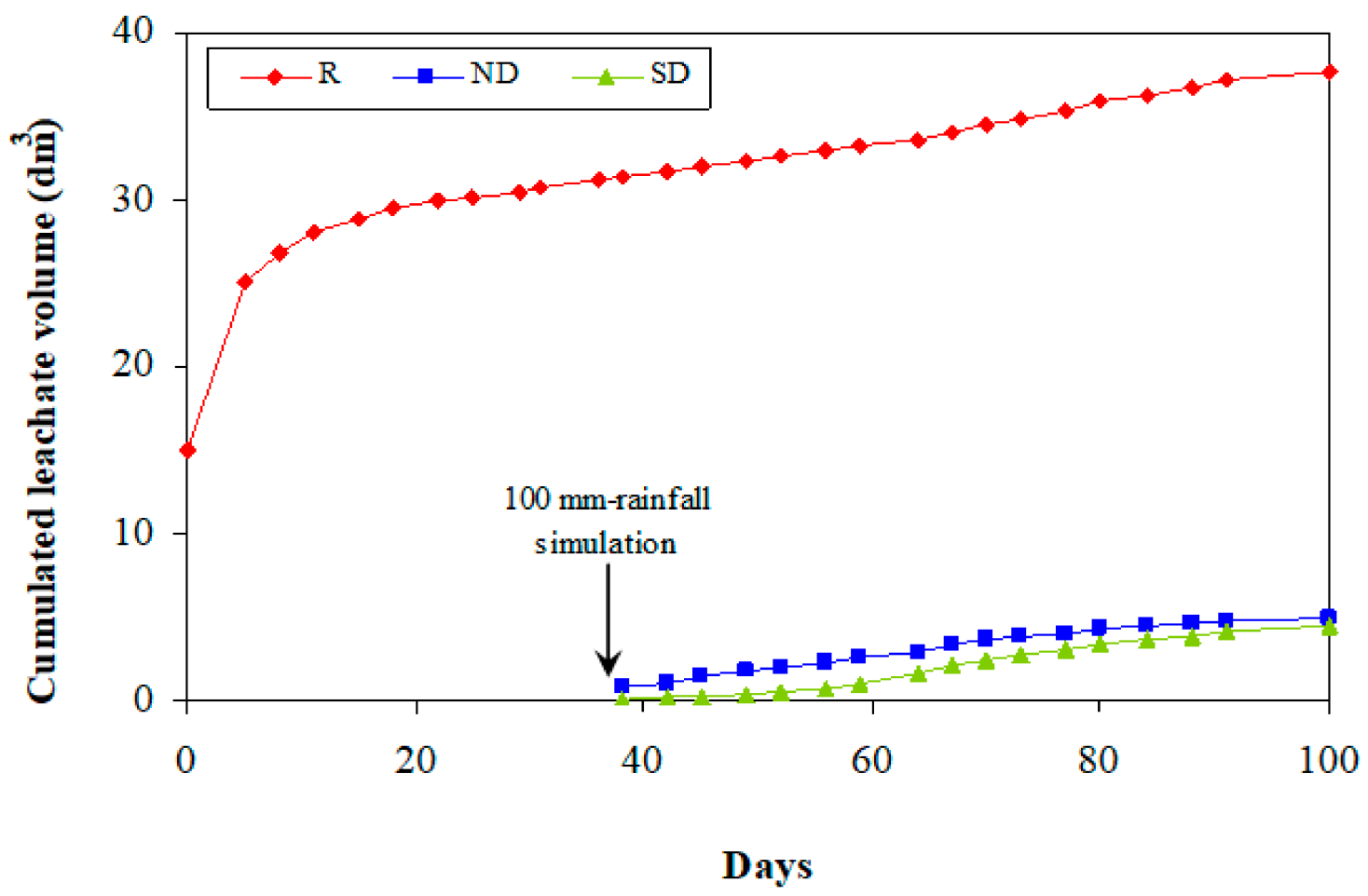

Figure 3. Temporal variation of leachate volumes in the lysimetric tests (R, raw OP; ND, naturally drained OP + rainfall; SD, solar-dried OP + rainfall).

In the other two tests, the cumulated volumes of leachate in the lysimeters after the simulated rainfall were $12.7 \mathrm{~mm}$ (about $4.9 \mathrm{~L}$ ) for “ND" OP and $11.4 \mathrm{~mm}$ (about $4.4 \mathrm{~L}$ ) 
for "SD" OP. These volumes were significantly lower than that produced by raw OP (" $R$ " test) and, in both cases, about $10 \%$ of the simulated rainfall, even despite the long time elapsed from rainfall simulation (which allowed a total drainage of OP through the soil layer) (Figure 3). According to our tests, the leachate volume from OP exposed to a heavy storm is therefore negligible compared to that produced by the drainage of raw OP.

This is most probably due to the high water absorption capacity of OP linked also to the presence of pectin. During rainfall, water is therefore not released but held by the biomass and then evaporated. This is an important issue when dealing with a potential organic pollution of the soil since the risk is limited to the period immediately following the land spreading.

Table 3 reports the mean values of the physico-chemical characteristics of the OP leachate monitored during the experiments. In more detail, in all tests $\mathrm{pH}$ and electrical conductivity showed a small variability over time. The $\mathrm{pH}$ increased on average from 7.6 to 8.2 (ND test) and from 7.9 to 8 (SD) in more than 60 days. A higher $\mathrm{pH}$ variation (from 7.0 to 8.5 ) was observed on the leachate from the $R$ test. The mean electrical conductivity decreased from 2.6 to $1.4 \mathrm{mS} \mathrm{cm}^{-1}$ for the ND test, and was practically constant for the SD (1.1-1.2 $\mathrm{mS} \mathrm{cm}^{-1}$ ) and the $\mathrm{R}$ (equal to $1.4 \mathrm{mS} \mathrm{cm}^{-1}$ ) tests.

Table 3. Main average physico-chemical properties of the leachate produced by the orange peel (OP) in the lysimetric tests.

\begin{tabular}{ccccc}
\hline \multirow{2}{*}{ Parameter } & \multirow{2}{*}{$\begin{array}{c}\text { Measuring } \\
\text { Unit }\end{array}$} & \multicolumn{3}{c}{ OP Test } \\
\cline { 3 - 5 } $\mathrm{pH}$ & - & $\mathbf{R}$ & $\mathrm{ND}$ & $\mathrm{SD}$ \\
\hline Electrical conductivity & $\mathrm{mS} \mathrm{cm}^{-1}$ & 1.4 & 2.2 & 1.2 \\
\hline Cumulated volume & $\mathrm{L}$ & 37.7 & 4.9 & 4.4 \\
\hline Chemical Oxygen Demand (COD) & $\mathrm{g} \mathrm{L}^{-1}$ & 4.4 & 1.8 & 0.7 \\
\hline Total COD & $\mathrm{g}$ & 166 & 8.8 & 3.1 \\
\hline Notes: $\mathrm{R}$, raw OP; ND, naturally drained OP + rainfall; SD, solar-dried OP + rainfall. &
\end{tabular}

The values of the COD were noticeably different among the three tests, and also for this parameter small temporal variations were measured. Specifically, the mean COD concentration decreased from 4.6 to $4.2 \mathrm{~g} \mathrm{~L}^{-1}$ for $\mathrm{R}$ test and from 0.8 to $0.5 \mathrm{~g} \mathrm{~L}^{-1}$ for SD test. In contrast, ND test showed an increase of the leachate COD from 1.5 to $2.0 \mathrm{~g} \mathrm{~L}^{-1}$. The lower COD measured for the ND and SD tests compared to the R test may be due to both the fact that most of the soluble organic matter was lost during drainage/drying and to the water added with the simulated rainfall, which diluted the residual dissolved organic matter in the leachate. The lower COD in leachate of the SD test compared to the ND test was presumably due to the lower re-hydration capacity of the previously dried biomass to re-hydrate and release of organic substances.

Shortly, the leachate analysis showed (Table 3):

- A slight increase in $\mathrm{pH}$ in naturally-drained ("ND" test, $\mathrm{pH}=7.8$ ) and solar-dried ("SD", 7.9) OP compared to the raw biomass (" $\mathrm{R}$ ", 7.3);

- A noticeably higher concentration of COD in the leachate released from raw OP (" $R$ " test, $\mathrm{COD}=4.4 \mathrm{~g} \mathrm{~L}^{-1}$ ) compared to the OP exposed to the rainfall ("ND", $1.8 \mathrm{~g} \mathrm{~L}^{-1}$ and "SD", $0.7 \mathrm{~g} \mathrm{~L}^{-1}$ );

- A total COD amount in the leachate from the raw OP ("R" test) of $166 \mathrm{~g}$, that is about 20 -fold and 50-fold higher than that released from the biomass subjected to rainfall simulation ("ND", $8.8 \mathrm{~g}$ and "SD", $3.1 \mathrm{~g}$ ).

The electrical conductivity in the leachate ranged from 1.2 (solar-dried OP) to 2.2 (naturally drained $\mathrm{OP}+$ rainfall) $\mathrm{mS} \mathrm{cm}^{-1}$. The increase in $\mathrm{pH}$ (on average by about $8 \%$ ) in the "ND" and "SD" tests could be due to the leaching by the simulated rainfall of residual alkali used in the preliminary liming and then dried. 
The OP natural drainage was most probably not able to noticeably increase the organic content of soil, given that the COD of leachate collected in the lysimeters in the worst case (166 $\mathrm{g}$ in the raw OP, " $\mathrm{R}$ " test) was lower by two orders of magnitude than the organic matter content in the natural soil. Since the COD contents in the leachate produced in "ND" and "SD" are even lower, the organic matter released after a heavy storm is negligible compared to the amount released by raw OP. Furthermore, the organic matter leached to soil is subject to prompt humification and is then beneficial for soil fertility.

The pollution risk due to the release of leachate during OP drainage seems to be very limited and not worsened by heavy storms.

\section{Conclusions}

The lysimetric tests of this study have shown that the drainage of raw orange peel produces a leachate that is only $20 \%$ of initial biomass volume, while the by-product exposed to heavy rainfalls (naturally drained or solar-dried) releases less than $2-3 \%$ of the simulated rainfall volume as leachate. The leachate from natural drainage of raw orange peel has a higher COD concentration compared to the biomass subjected to rainfall simulations. In all cases, the COD released on soil is very low and negligible compared to the natural organic content of soil. Therefore, the study demonstrates that the natural drainage of orange processing residues is not hazardous for soil health, while, in contrast, it provides a beneficial addition of organic matter for the soil fertility. Heavy storms are not able to aggravate the pollutions risk for soil. Nevertheless, suitable countermeasures should be adopted when orange peel is placed in open air on steep slopes, to avoid the possible runoff of leachate towards surface water bodies.

Overall, although these preliminary results are encouraging to promote a cheap and environmentally sound valorisation of citrus residues, further tests have to be planned on soils of different types and under variable climatic conditions.

Author Contributions: Conceptualisation, P.S.C., D.A.Z. and S.M.Z.; methodology, S.A., A.F., P.S.C., D.A.Z. and S.M.Z.; validation, P.S.C., D.A.Z. and S.M.Z.; formal analysis, P.S.C., D.A.Z. and S.M.Z.; investigation, S.A., A.F., P.S.C., D.A.Z. and S.M.Z.; resources, S.M.Z.; data curation, S.A. and A.F.; writing—original draft preparation, S.A. and D.A.Z; writing—review and editing, A.F., P.S.C., D.A.Z. and S.M.Z.; supervision, S.M.Z.; project administration, S.M.Z.; funding acquisition, S.M.Z. All authors have read and agreed to the published version of the manuscript.

Funding: This research received no external funding.

Data Availability Statement: No new data were created or analyzed in this study. Data sharing is not applicable to this article.

Conflicts of Interest: The authors declare no conflict of interest.

\section{References}

1. Zema, D.A.; Calabrò, P.S.; Folino, A.; Tamburino, V.; Zappia, G.; Zimbone, S.M. Valorisation of citrus processing waste: A review. Waste Manag. 2018, 80, 252-273. [CrossRef] [PubMed]

2. FAO FAOSTAT-Crops Production. Available online: http://www.fao.org/faostat/en/\#data (accessed on 4 May 2021).

3. Nam, I.S.; Garnsworthy, P.C.; Ahn, J.H. Supplementation of essential oil extracted from citrus peel to animal feeds decreases microbial activity and aflatoxin contamination without disrupting in vitro ruminal fermentation. Asian Australasian J. Anim. Sci. 2006, 19, 1617-1622. [CrossRef]

4. Bousbia, N.; Abert, M.; Ferhat, M.A.; Meklati, B.Y.; Chemat, F. A new process for extraction of essential oil from Citrus peels: Microwave hydrodiffusion and gravity. J. Food Eng. 2009, 90, 409-413. [CrossRef]

5. Mahato, N.; Sharma, K.; Koteswararao, R.; Sinha, M.; Baral, E.; Cho, M.H. Citrus essential oils: Extraction, authentication and application in food preservation. Crit. Rev. Food Sci. Nutr. 2017, 4, 1-15. [CrossRef]

6. Hull, W.Q.; Lindsay, C.W.; Baier, W.E. Chemicals from oranges. Ind. Eng. Chem. 1953, 45, 876-890. [CrossRef]

7. Moufida, S.; Marzouk, B. Biochemical characterization of blood orange, sweet orange, lemon, bergamot and bitter orange. Phytochemistry 2003, 62, 1283-1289. [CrossRef]

8. Arce, A.; Marchiaro, A.; Martínez-Ageitos, J.M.; Soto, A. Citrus Essential Oil Deterpenation by Liquid-Liquid Extraction. Can. J. Chem. Eng. 2005, 83, 366-370. [CrossRef] 
9. Zema, D.A.; Calabro, P.S.; Folino, A.; Tamburino, V.; Zappia, G.; Zimbone, S.M. Wastewater management in citrus processing industries: An overview of advantages and limits. Water 2019, 11, 2481. [CrossRef]

10. Goodrich, R.M.; Braddock, R.J. Major By-Products of the Florida Citrus Processing Industry; University of Florida: Gainesville, FL, USA, 2006.

11. Kimball, D.A. Citrus Processing: A Complete Guide; Springer: New York, NY, USA, 1999; ISBN 9781461549734.

12. Sharma, K.; Mahato, N.; Cho, M.H. Converting citrus wastes into value-added products: Economic and environmently friendly approaches. Nutrition 2017, 34, 29-46. [CrossRef] [PubMed]

13. Calabrò, P.S.; Pontoni, L.; Porqueddu, I.; Greco, R.; Pirozzi, F.; Malpei, F. Effect of the concentration of essential oil on orange peel waste biomethanization: Preliminary batch results. Waste Manag. 2016, 48, 440-447. [CrossRef]

14. Zema, D.A. Planning the optimal site, size, and feed of biogas plants in agricultural districs. Biofuels Bioprod. Biorefining 2017, 11, 454-471. [CrossRef]

15. John, I.; Muthukumar, K.; Arunagiri, A. A review on the potential of citrus waste for D-Limonene, pectin, and bioethanol production. Int. J. Green Energy 2017, 14, 599-612. [CrossRef]

16. Satari, B.; Palhed, J.; Karimi, K.; Lundin, M.; Taherzadeh, M.J.; Zamani, A. Process optimization for citrus waste biorefinery via simultaneous pectin extraction and pretreatment. BioResources 2017, 12, 1706-1722. [CrossRef]

17. Gelsomino, A.; Abenavoli, M.R.; Princi, G.; Attinà, E.; Cacco, G.; Sorgonà, A. Compost from Fresh Orange Waste: A Suitable Substrate for Nursery and Field Crops? Compost Sci. Util. 2010, 18, 201-210. [CrossRef]

18. Sorgonà, A.; Abenavoli, M.R.; Cacco, G.; Gelsomino, A. Growth of Tomato and Zucchini Seedlings in Orange Waste Compost Media: pH and Implication of Dosage. Compost Sci. Util. 2011, 19, 189-196. [CrossRef]

19. Gelsomino, A.; Abenavoli, M.R.; Sorgonà, A. Above- and below-ground morphological responses of a citrus rootstock interfered with orange waste compost: An evaluation as a component of growing media. Agrochimica 2014, 58, 148-164.

20. Bampidis, V.A.; Robinson, P.H. Citrus by-products as ruminant feeds: A review. Anim. Feed Sci. Technol. 2006, 128, 175-217. [CrossRef]

21. Madrid, J.; Hernández, F.; Pulgar, M.A.; Cid, J.M. Urea and citrus by-product supplementation of straw-based diets for goats: Effect on barley straw digestibility. Small Rumin. Res. 1997, 24, 149-155. [CrossRef]

22. Gohl, B.I. Citru by-product for animal feed. In Ruminant Nutrition: Selected Articles from the World Animal Review, FAO Animal Production and Halth Paper; FAO: Rome, Italy, 1978.

23. Caparra, P.; Foti, F.; Scerra, M.; Sinatra, M.C.; Scerra, V. Solar-dried citrus pulp as an alternative energy source in lamb diets: Effects on growth and carcass and meat quality. Small Rumin. Res. 2007, 68, 303-311. [CrossRef]

24. Tamburino, V.; Zema, D.A.; Zimbone, S.M. Orange Peel Utilizations in Southern Italy. In Proceedings of the CIGR Section VI International Symposium on Food and Agricultural Products: Processing and Innovations, Naples, Italy, 24-26 September 2007.

25. Bombino, G.; Denisi, P.; Fortugno, D.; Tamburino, V.; Zema, D.A.; Zimbone, S.M. Land spreading of solar-dried citrus peel to control runoff and soil erosion. WIT Trans. Ecol. Environ. 2010, 140, 145-154.

26. Górka, A. Threats to Rural Landscape and Its Protection in Poland. Environments 2018, 5, 109. [CrossRef]

27. Huang, T.; Lo, K. Effects of Land Use Change on Sediment and Water Yields in Yang Ming Shan National Park, Taiwan. Environments 2015, 2, 32-42. [CrossRef]

28. Diodato, N.; Guerriero, L.; Bellocchi, G. Modeling and Upscaling Plot-Scale Soil Erosion under Mediterranean Climate Variability. Environments 2017, 4, 58. [CrossRef]

29. Botta, G.; Brignoli, V.; Alberti, M.; Riva, G.; Scrosta, V.; Toscano, G. Analisi delle iniziative per la produzione di energia elettrica da biomasse agro-industriali in Italia. In Proceedings of the Atti IV Convegno Nazionale “Utilizzazione Termica dei Rifiuti"-Relazioni Tecniche, Abano Terme, Italy, 12-13 June 2003; pp. 12-13.

30. Siles, J.Á.; Martín, M.D.L.Á.; Martín, A.; Raposo, F.; Borja, R. Anaerobic digestion of wastewater derived from the pressing of orange peel generated in orange juice production. J. Agric. Food Chem. 2007, 55, 1905-1914. [CrossRef] [PubMed]

31. Negro, V.; Mancini, G.; Ruggeri, B.; Fino, D. Citrus waste as feedstock for bio-based products recovery: Review on limonene case study and energy valorization. Bioresour. Technol. 2016, 214, 806-815. [CrossRef]

32. Tamburino, V.; Zimbone, S.M. Solar drying processes of citrus peel. In Proceedings of the XIII International CIGR Congress on Agricultural Engineering, Rabat, Marocco, 2-6 February 1997; pp. 2-6.

33. Andiloro, S.; Tamburino, V.; Zimbone, S.M. Indagini sui processi di drenaggio ed evaporazione da pastazzo di arancia. In Valorizzazione di Acque Reflue e Sottoprodotti dell'Industria Agrumaria e Olearia; Laruffa Editore: Reggio Calabria, Italy, 2004.

34. Fazzino, F.; Mauriello, F.; Paone, E.; Sidari, R.; Calabrò, P.S. Integral valorization of orange peel waste through optimized ensiling: Lactic acid and bioethanol production. Chemosphere 2021, 271, 129602. [CrossRef]

35. Calabrò, P.S.; Panzera, M.F. Biomethane production tests on ensiled orange peel waste. Int. J. Heat Technol. 2017, 35, 130-136. [CrossRef]

36. TT Le, A.; Kasahara, T.; Vudhivanich, V. Seasonal Variation and Retention of Ammonium in Small Agricultural Streams in Central Thailand. Environments 2018, 5, 78. [CrossRef]

37. Malini, R.; Tajuddin, R.M.; Sa'adah, N.; Hamid, A. Citrus Fruit Waste Leachate Treatment By Using Newly Developed Flat Sheet Membrane. Int. J. Sci. Res. Publ. 2018, 8, 83. [CrossRef]

38. Bombino, G.; Denisi, P.; Gómez, J.; Zema, D. Water Infiltration and Surface Runoff in Steep Clayey Soils of Olive Groves under Different Management Practices. Water 2019, 11, 240. [CrossRef] 
39. Bombino, G.; Denisi, P.; Gómez, J.A.; Zema, D.A. Mulching as best management practice to reduce surface runoff and erosion in steep clayey olive groves. Int. Soil Water Conserv. Res. 2021, 9, 26-36. [CrossRef]

40. Walkley, A.; Black, I.A. An examination of the degtjareff method for determining soil organic matter, and a proposed modification of the chromic acid titration method. Soil Sci. 1934, 37, 29-38. [CrossRef]

41. Bremmer, J.; Mulvaney, C. Nitrogen total. In Methods of Soil Analysis; Page, A., Miller, R., Keeney, D., Eds.; American Society of Agronomy: Madison, WI, USA, 1982; pp. 595-624.

42. IRSA-CNR. Metodi Analitici per le Acque; IRSA-CNR, Ed.; Istituto di Ricerca Sulle Acque, Consiglio Nazionale delle Ricerche: Rome, Italy, 1994. 